\title{
Gustav Weigand, Armânii. Cercetări etnografice, filologice-istorice asupra așa numiților macedo-romani sau țințari de Gustav Weigand. Volumul I. Țară și oameni. Cu o ilustrație de titlu, 8 fotografii și o hartă, Editura Tracus Arte, București, 2014, $398 \mathrm{p.}^{\dagger}$
}

\author{
Nistor Bardu* \\ Faculty of Letters,"Ovidius” University of Constanța, Aleea Universității 1, 900472 Constanța, Romania
}

1. Well-known among Romanian linguists, and often quoted in applied linguistics studies, especially in those on Romanian dialectology and the history of the Romanian language, the work of the German scholar Gustav Weigand, Die Aromunen. Etnographisch-philologisch-historische Untersuchungen über das Wolk der sogenannten MakedoRomanen oder Zinzaren. Land und Leute, Mit einem Titeldilde, 8 Tefelsundeinen Karte, Leipzig, Johann Ambrosius Barth (Arthur Meiner), $1895^{1}$ has been recently translated into Romanian under the title Armânii. Cercetări etnografice, fllologice-istorice asupra așa numiților macedo-romani sau țințari de Gustav Weigand. Volumul I Țară și oameni. Cu o ilustrație de titlu, 8 fotografii și o hartă, (București, Editura Tracus Arte, 2014). It is for the first time that the Weigand's work has been printed in Romanian. Since this is only the first volume, we share the conviction that the translator will give us the Romanian version of the second volume as well.

The fact that this happened more than 120 years after the publication of the book in German might be a matter of concern to the general public. However, much more interesting than this aspect seems to be the fact that Romanian specialists in the field have never complained of the absence of a Romanian version of Weigand's work. In our opinion, the reasons could be as follows:

On the one hand, for linguists, the first volume of Weigand's Die Aromunen is less relevant than the second volume (it appeared before the first, in 1894 !), and which includes the dialectal texts compiled by the author from the Aromanians he met during his travels in the Balkans. On the other hand, as far as historical and ethnographic information on the Aromanians is concerned, the public opinion in the modern Romanian state (after the 1859 Union of the Romanian Principalities) did not have to wait for Gustav Weigand to learn about the existence of the branches of Romanians living in the Balkans. Starting with the latter part of the $19^{\text {th }}$ century, Romanians in the Principalities were provided with an increasing amount of data about their Balkan brothers. In a 2003 study, the historian Stoica Lascu, from Ovidius University of Constanta, shows that it was the 1848 revolutionaries (Chr. Tell, I. H. Rădulescu, D. Brătianu, C. Negri, Ion Ionescu de la Brad, I. Ghica) who first "came into direct contact with the descendants of Balkan Romanity, in their native settlements, within the borders of European Turkey" (Lascu, 2003, p. 257). The earliest direct, ethnographic and linguistic evidence, dating back to 1852 , is provided by the travel account of Ion Ionescu de la Brad: he encountered "Aromanian shepherds, coming from the Epirus and the Macedonian mountains to winter their numerous herds in the beautiful and large plains of Thessaly", talked to them and learned from them that they were Romanians ("Him rumâni"), that is Vlachs, Christians. Dimitrie Bolintineanu's book Călătorii la românii din Macedonia și Muntele Athos sau santa Agora [Travels to the Romanians from Macedonia and Mount Athos or Santa Agora], published in 1863, is even more informative about the Balkan brothers of the Romanians than the previous report. Even if the data furnished by the author are mostly bookish, as Th. Capidan showed later on (1932, p. 41; see also Lascu, 2003, p. 260), they played an important role

\footnotetext{
${ }^{\dagger}$ A first version of this text was published under the title Gustav Weigand răstălmăcit! on May 23, 2016, in the newspaper "Constanța noastră".

*Email address: nistor_bardu@yahoo.com.

${ }^{1}$ We have exactly reproduced the title and the other data included in the title page, which we have scanned and rendered as such in the translated volume (p. 4). As matter of fact, the original volume had two title pages.
} 
in "making Romanians aware of the existence, the history and the civilization of these descendants of Balkan Romanity" (Lascu, 2003, p. 262). Following visits in the region, other authors, such as Radu C. Pătârlăgeanu and Alexandru Pencovici wrote and published their own accounts: Călătorii in Macedonia, Thesalia și Muntele Athos de... [Travels into Macedonia, Thessalia and Mount Athos], Ploiești, 1884 and Despre românii din Macedonia și Muntele Athos. Impresiuni de călătorie de... [On the Romanians from Macedonia and Mount Athos. Travel impressions], București, 1885, respectively (Lascu, 2003, p. 269-270). In 1895, when Weigand had the first volume of Die Aromunen printed in Leipzig, Ioan Nenițescu saw his magnum opus, Dela Românii din Turcia Europeană. Studiu etnic și statistic asupra armanilor [From the Romanians from European Turkey. Ethnic hand Statistical Study on Aromanians] published in Bucharest. Not less imposing by its dimensions (643 pages, with numerous photos) and by its content, the work of Ioan Nenițescu produced a strong impression upon the public mind, despite the fact that many of the historical, geographical and ethnographic facts and figures concerning the Romanian schools in the area, which he provides, come neither from his direct observations, nor from his face-to-face discussions with the Aromanians, but from other people's travel relations. In the first decades of the $20^{\text {th }}$ century, better and better informed Romanian travelers, some of them of aromanian origin, began collecting ever more precise historical, social, linguistic, ethnographic, folklore and statistic data about the Romanian schools or the Balkan Aromanians, whom they met, photographed and interviewed, in their own natural environment, and in the circumstances of their daily life. Worth mentioning, in this regard, are Al. Rubin, Pericle Papahagi (for his information about the MeglenoRomanians), Constantin N. Burileanu (for the data about the Aromanians in Albania), I. Manu, C. Istrati, Mihail-Virgiliu Cordescu and others ${ }^{2}$

Therefore, at the time when volumes II and I of Gustav Weigand's Die Aromunen appeared in print in Leipzig (in 1894 and 1895, respectively), the public opinion in Romania possessed enough knowledge about the general status of Aromanians in the Balkan Peninsula. After this date, information about them became more abundant, more systematic and exact.
In the inter-war and postwar period, this preoccupation reached its climax with the studies of such reputed linguists of aromanian origin as Th. Capidan, Tache Papahagi, Matilda Caragiu Marioțeanu, Nicolae Saramandu, Gheorghe Caragiani and others. Even today, their works meet the exigencies of the researchers in the domain and are often consulted and quoted. This is the real cause for which Weigand's work has not been translated so far into Romanian, and not another, as the editor Mariana Bara leaves to be understood, in the afterword of the book, "O călătorie la armâni" [A Travel to Aromanians], which she calls a "critical study", when she writes the following: "Although Weigand is an author of reference, frequently quoted by specialists, his work has not been translated into Romanian so far" (Weigand, 2014, p. 390).

On the other hand, the editor herself underlines that, at the time of his travels through the region, recorded in Die Aromunen, I, Weigand "was at the beginning of his scientific career (he is 29 year old when he begins his travels, and only 26 when he carries this research in the field, among the Aromanians from Olympus)", and that "be minutely describes the dialects of Aromanian in his volume on folklore, but adopts a system of phonetic transcription (phonetically faithful), difficult enough and unused by other authors. That is why the present volume must be read as a travel account, as the German public perceived it in 1895 (emphasis added N.B.); it does fit the paradigm of travel narratives, the more so as, at the time, the Balkans was an unknown zone, sufficiently exotic and colourful to draw public attention" (Weigand, 2014, p. 390-391).

In other words, Mariana Bara alerts readers that the work she comments upon in the critical study should be seen as a youth work project, and not as Weigand's magnum opus, aimed at a German audience, and not at a Romanian one! This been said, any reproach that Die Aromunen has not been translated so far seems unfair.

2. On the title page of the translation (Weigand, 2014, p. 3), after the elements of the title and the subtitle in the original, more exactly, after the words Volumul I. Țară și oameni. Relatarea autorului despre călătoriile sale în sud-vestul Peninsulei Balcanice, insoțită de trei anexe științifice, o ilustrație de titlu, opt tabele, opt fotogravuri și o hartă etnografică [Volume

\footnotetext{
${ }^{2}$ For further details see Lascu (2003, p. 277ff.).
} 
I. The Country and the People. The author's account of his travels in the south-west of the Balkan peninsula, accompanied by three scientific annexes, a title illustration, eight tables, eight photo-engravings, and an ethnographic map], the Romanian editors insert the following explanatory note: "Traducere din limba germană și note de Christian Bandu. Ediție ingrijită de Mariana Bara (revizia traducerii în limba română, studiu critic, note, bibliografie)" [Translation from German and notes by Christian Bandu. Edited by Marina Bara (revision of the Romanian translation, critical study, notes and bibliography]. No indications given as to which notes belong to the translator and which to the editor. We can only presume that Christian Bandu authored the final notes in the Cuvint inainte [Foreword] and those in the chapters and the annexes (p. 335-346). It is not clear which could be Mariana Bara's notes, but we are sure that, in addition to the "critical study" at the end of the volume, entitled $O$ călătorie la armâni [A travel to the Aromanians] (p. 347-391), a sort of afterword of the book, Lista cronologică selectivă a lucrărilor publicate de Gustav Weigand [The chronological list of the works published by Gustav Weigand] (p. 396) and Notă asupra ediției [Note on the edition] (p. 397) are hers. These aspects need to be clarified in order to establish who carries responsibility for the statements included in the technical apparatus of the book.

3. What takes the Romanian dialectologists by surprise, from the very cover, from the two title pages and afterwards, in the text, is the fact that the translator equates the term Die Aromunen, coined by Weigand in his book, as Armânii instead of Aromânii [Aromanians], as has been interpreted, accepted, and used by specialists in the field for the last 120 years. The explanation given by the translator (Christian Bandu?) in Note finale la «Cuvint înainte» [Final notes to Foreword] is stupefying:

"The German appellative Aromunen has been wrongly equated in Romanian with aromâni [...] Romanian philologists, historians, ethnographers, ethnomusicologists, writers, etc. such as Pericle Papahagi, Theodor Capidan, Tache Papahagi, Victor Papacostea, Valeriu Papahagi, Ioan Caranica, George Marcu, Matilda Caragiu Marioțeanu, Hristu Candroveanu, etc. use the term in their works; today it is widely used in mass-media, public life, a.s.o. If Weigand had said «aromâni» in German, the word would have been «Arumänen», since, in German, «români» translates by «Rumänen» and not by «Romunen». In addition to lack of information, «the theses of Romanian national ideology in regard to the Aromanian problem» largely accounts for the use of the appellative «aromani» instead of «armâni» (emphasis added N.B.!) (Mariana Bara, Limba armânească, Cartea universitară, București, 2007, p. 13).”

$$
\text { (apud Weigand, 2014, p. 335) }
$$

First of all, the translator and, then, the editor of the book, Mariana Bara, quoted by the translator in his own note as an authority in the respective problem, forget, in the text above-mentioned, that the appellative aromân [Aromanian] is commonly used by almost all Romanian researchers, be they linguists, historians, folklorists, ethnomusicologists, writers etc., as well by many foreign authors ${ }^{3}$. That is why it has received wide currency in Romanian linguistics and has penetrated foreign languages of international circulation, such as English (Aromanians) and French (Aroumains, cf. Dictionnaire 1994, s.v. aroumain). Does this mean that the authors of English and French dictionaries are "uninformed" and/or have been seized by the Romanian nationalist frenzy too?

Secondly, Weigand never says that the term Aromunen, which he coined, refers to armâni only. On the contrary, he had indicated, from the second volume, published a year earlier (1894), that the German Aromunen is a general term which comprises all those that call themselves Armâni, Arămâni, Arămeñi (ori farșeroți). In his own words,

"Im Aromunischen lautet der Name: Armấn im

\footnotetext{
${ }^{3}$ We shall only mention some of them here: Nicolae Iorga, Constantin C. Giurescu, G.I. Brătianu, Dușan Popovici, Nicolae Șerban Tanașoca, Neagu Djuvara, Carlo Tagliavini, Ovid Densusianu, Sextil Pușcariu, Alexandru Rosetti, Emil Petrovici, Alexandru Graur, Boris Cazacu, Emanuel Vasiliu, Dimitrie Macrea, Ion Coteanu, Romulus Todoran, Grigore Brâncuş, Marius Sala, Cicerone Poghirc, G. I. Tohăneanu, Petre Ș. Năsturel, Nicolae Saramandu, Liliana Ionescu Ruxăndoiu, Adrian Poruciuc, Petru Neiescu, Vasile Arvinte, Constantin Frâncu, Gheorghe Carageani, Petar Atanasov, Eugeniu Coșeriu, Max Demeter Peyfuss, Thede Kahl, Paul Garde etc. etc. In Mr Christian Bandu's logic, all these prestigious Romanian and foreign scientists are equally uninformed or prisoners of "the theses of Romanian national ideology in regard to the Aromanian problem"!
} 
Centrum und Süden, Arămăńn (Arumăñ?) im Norden, Arămén ${ }^{4}$ bei einigen Faršeriotenstämmen; Aromunen ist die deutsche Form, die am besten der nördlichen einheimishchen, entspricht, ich werde die daber in Zukuft ausschließlich gebrauchen" ["In Aromanian, the following appellatives are used: armân in the centre and in the south, arămăn (arumăñ?) in the north, arămén within some Farsherot communities. Aromunen is the German corresponding term that refers to the northern communities, and is the term that I am going to use from now on too"] (emphasis added, N.B.)

(cf. Weigand, 1894, p. VIII)

It follows that the appellative armân is the name of one group of Aromanians known to Weigand, more precisely, those living in the south and the centre (of the Balkan Peninsula). Therefore, it is a regional appellative, and not one that comprises all Aromanians.

In the first volume, Weigand reasserts this linguistic reality that he encountered in the field, the translation of which we discuss here. Unable to find corresponding equivalents to such appellatives as "Macedo-Vlachs", "southern Romanians", "Pindus Vlachs", "trans-Danubian Vlachs", "Cutzo-Vlachs", "Tzintzars", Weigand coined the ethnonym "Aromunen" "which is the German equivalent of the word arămâni” (emphasis added) (Weigand, 2014, p. VII). In other words, it refers to all the Aromanians whose idiom is characterized by $/ a /$ phonetic prosthesis.

We see clearly once again that it is not about the appellative armâni, as the author of note 2 on page 335 (Christian Bandu?), and Mariana Bara, in her considerations on pages 361-363, interpret the term Aromunen, totally ignoring Weigand's own statements from volume II (1894), but about arămâni. That is, aromâni [Aromanians], as the specialists in the field have correctly interpreted it until now. If he had wanted to include all the Aromanians under the name of armâni, the author would have used the term Armấn, mentioned in the 1894 volume (see supra), with the specification that it refers only to the Aromanians from the centre and the south of the Balkan Peninsula, whom he encountered during his travels in the region!

The conclusion that imposes itself is that thus both the translator and the editor of this first volume of the celebrated (for us, Romanians!) work Die Aromunen by Weigand have distorted the translation of the name of the Aromanians on the front cover, the half title, and the title page, and then everywhere in the text where the German author uses the term Aromunen and/or its derivates and flexionary forms (aromunisch, aromunische, aromunischen, aromunischer, aromunisches), and, by doing this, they compromised the Romanian version as a whole. Shame for the effort that was made!

4. A question now arises: How did Gustav Weigand came to use the appellatives arămâníi (arumăñ?), arămeńi in volume II (1894, p. VIII) and arămâni in volume I (1895, p. VII), in connection to which he offers his own explanations?

As known sources show, the appellative arămân can be heard nowhere among the Aromanians: neither among the Pindus, nor the Gramostean ones, who call themselves armâni, and not among the Aromanians from Albania. If Weigand had heard such an appellative, it must have been very rare. It may also be an ad-hoc creation. One of the appellatives used by the Aromanians from Albania is rămănii, a form first recorded in the 1797 Abecedar [Primer] of Constantin Ucuta, with its derivatives rrămăneasca, rrămănești (Papahagi, 1909, p. 67). Later on, in 1895 , in his own relations, Ioan Nenițescu generalizes the term armân to include all the Aromanians whom he visited or about whom he had heard. However, citing Ioan Caragiani, he notes that the Aromanian Farsherots had always called themselves Rumâni or Rumeni (Nenițescu, 1895, p. 183). Constantin N. Burileanu (1906) also recorded the form rrmăn, among the Farsherots, and in the title of his book, he uses the appellative romăni: De la Romănii din Albania. The form rămăni is confirmed by all those who have carried field research among the Aromanians in Albania. We first quote Weigand's own pupil, Th. Capidan, who direct lymet the Albanian Farsherots (cf. Capidan, 1931, p. 1-210), and heard them calling themselves rumăni, romăñi, or rămăni , the last term functioning as a generic name

\footnotetext{
${ }^{4}$ Since in German there are no $\breve{a}$ and $\hat{\imath}(\hat{a})$ vowels, which are specific of the phonetic system of the Aromanian dialect, we must specify that in order to render them Weigand uses the letter $u$, with a circle under it $(u)$, for $\hat{a}$, and the letter $o$, with a circle under it $(o)$, for $\breve{a}$.
} 
(Capidan, 1931, p. 170; 1932, p. 3-4), Nicolae Saramandu (2003, p. 24; 2004, p. 86; 2007, p. XXXIXXXII), Petru Neiescu (1997, p. 27ff.), etc. During the field research that we conducted in Albania, we too recorded the forms rămăn ${ }^{i}$, among the Moscopolean Aromanians and rămén ${ }^{i}$ (with an open $(e /)$, among the Farsherots from Divjaka, Elbasan, Boboștița and Gjirokastër. Our hypothesis is that the form Arămân, in volume I of Weigand's Die Aromunen, was coined by the German author, although it is not based on any phonetic rule. As it is known, la/ prosthesis appeared in the ethnonym rumânu (< Lat. romanus), due to the forte pronunciation of the initial $/ r /$, a pronunciation that is specific to the idioms of many south-Danubian Romanians. In the resulting form, arumân ${ }^{u}$, the unstressed vowel $/ u$, after $/ r /$, syncopated, probably because of the forte pronunciation of $/ r /$, thus resulting in $\operatorname{arma} n^{u}$. However, with other Aromanians located in the northwest of the Balkan Peninsula, as Th. Capidan (1932, p. 224-227) noticed, /a/ prosthesis is rare or absent from the ethnic appellative among the Aromanians in Albania, either Farsherot or Moscopolean 5 . To our knowledge, the form arămâni is attested by no one, except Gustav Weigand. Aromanians, when they do not call themselves after the name of their localities of origin-avdil'át (from Avdela), pirvul'át (from Perivole), sîrmînáț (from Samarina), ničót (from Nicea), etc. ${ }^{6}$-, they call themselves armân, farșerót, rămăń, rumăní, romăñi, răméń. Most likely, by using the form Arămân, in both volumes, Weig- and wished to give further justification to the term Aromunen, an ethnonym meant to include all the Macedo-Romanians.

5. Why Aromunen and not Arumänen? It is known that in German Rumänen is the term used to refer to Romanians. This appellative, together with its derivatives Rumäne, Rumänin, rumänisch, Rumänien (for the country's name) "has generalized and has remained in use until now in all the German speaking countries" (Arvinte, 2008, p. 198). The German appellative Rumänen dates, most likely, from the times when most Romanians called themselves rumâni ${ }^{7}$, because this is, as we have seen above, the result of the phonetic evolution of the Latin romanus ${ }^{8}$ in Romanian. Vasile Arvinte, an authority in RomanianGerman linguistic relations, draws attention to the fact that, until the respective forms became prevalent, other forms with $/ o /(:$ Rom...) had been circulating in German, ever since the $16^{\text {th }}$ century. Based on detailed research, Vasile Arvinte identified a number of sources that attest to their existence:

- the Transylvanian Saxon historiographer Johannes Lebel (1490-1566): Romuini (p. 200);

- J. Tröster (1666): Romunos: “...nennen sich Romunos..." (loc. cit.);

- a 1701 edict of Emperor Leopold: Romeni (loc cit.);

- an anonymous Austrian author (1701): "Wallachian and Moldovans are called in Hungarian Ola, in Transylvanian Saxon Bloch, in Romanian

\footnotetext{
${ }^{5}$ The Aromanians from Albania, whom Weigand encountered at Lănga, Elbasan, Berat, in the Muzakia plains, at Korça, Moscopole, Șipsca etc. call themselves rămăñ ${ }^{i}, r^{\hat{a}} m a \breve{n}^{i}, r r^{u} m a ̆ n$ or even $r r m a ̂ n$, all of which result from the same etymon: Lat. romanus > rumăn > rămăn > rrmân. This ethnonym lacks then prosthesis of /a/, which is rarer in the Aromanian idioms form Albania (cf. Bardu, 2004, p. 79-80).

${ }^{6}$ Cf. Saramandu (1984, p. 424; 2004, p. 82).

${ }^{7}$ It is worth mentioning, in this respect, the well-known words of Grigore Ureche, from Letopisețul Țării Moldovei [The Chronicle of Moldova]: "Rumânii cîți să află lăcuitori în Țara Ungurească și la Ardeal și la Maramoroșu, de la un loc sîntu cu moldovenii și toți de la Râm se trag" [Romanians, those who live in the Hungarian country, in Transylvania, and Maramuresh, come from the same homeland, and they all descend from Rome] (Ureche, 1987, p. 77).

It is equally true that the form român had been used popularly together with the form rumân, from times out of mind. Vasile Arvinte convincingly demonstrates this, with numerous arguments, in his philological study Român, românesc, România (2008). The conclusions the author reaches are unequivocal: "The discussion on the phonetic variants of român, respectively rumin has shown that they have an uncontested dialectal basis ... they are authentically popular, etymologically motivated, in the sense that their phonetic evolution is comparable to other inherited Latin elements. Their antiquity goes as far back as popular Latin. Some linguistic data in the Moldovan idiom (and other Daco-Romanian groups), but especially the situation in some Aromanian idioms, where a bookish influence is hard to admit, provides us with the proof that the variants with /o/ are previous to the influence of scholarly Latin. This influencer played an important role in imposing and generalizing the variants with / $/$ in the Romanian language, due to the constant reference of the Romanian ethnic name to the etymon romanus. From literary language, the variants could then enter the lexicon of dialects" (Arvinte, 2008, p. 64; see the entire subchapter Baza dialectală a variantelor român-rumân [The dialectal base of the român-rumân variants] from the chapter Numele etnic român (rumân) [The român (rumân) ethnic name], p. 33-64).

${ }^{8}$ Another result is the form român (see supra, footnote 6).
} 
they call themselves Romun.

The same author also signaled the presence of other variants as well: Romuin, Romulien, Romunx etc. (cf. Arvinte, 2008, p. 200-207).

We do not know whether, at the time he wrote the two volumes of Die Aromunen, Gustav Weigand had any knowledge of the existence, in German, of such forms as Romeni, Romun, Romunos, etc. It is beyond doubt that he was familiar with the form român, from the literary Romanian of the times, as different from the German one, as well as with the forms armân and (a)rămăn, the latter with variants mentioned above (Arumăń, Arămeñi, Fărșer$\boldsymbol{o t} \boldsymbol{t} i)$, which himself recorded among the MacedoRomanians whom he contacted during his travels. Our supposition is that, by coining and using the general form Aromunen, Weigand wished to show, on the one hand, that the Aromanians are different from the Daco-Romanians from modern Romania, and on the other hand, that, at some time in the past, both of them had constituted a linguistic unity, sharing the same territory, as he himself states in Die Aromunen (I, 1895, p. 271) (see infra).

6. In the logic of what we have said above, we think that the idea defended by Mariana Bara, namely that by creating the Aromunen term, Gustav Weigand wanted to distinguish between Aromanians and Romanians, in general, is false. He meant to distinguish the former from the Daco-Romanians, not from Romanians. This is what the German author writes, at p. 271 of the volume I, from Die Aromunen, about the four branches of Romanians:

"One can discuss about «romanici» only from an ethnographic view point. This also holds true for the Romanian people of whom the Aromanians are a branch only. The four Romanian peoples: the Daco-Romanians, the Aromanians ${ }^{9}$, the Megleno-Romanians and the HistroRomanians are closely connected with one another, through their language; however, language only shows that the people who now live separated from one another, must have inhabited the same space, at some time in the past." (emphasis added)

(Weigand, 2014, p. 271)

Such a statement defies any other interpretation of Weigand's conception of the dialectal unity of historic Romanian. It could be considered, as professor Marin Petrișor, from Ovidius University of Constanța, rightly notices, in an article yet unpublished, "a preamble to the theory on the common Romanian language (proto-Romanian), from which the dialects of Romanian bave branched out from", starting with the $10^{\text {th }}$ century A.D., a theory embraced by most Romanian and foreign linguists. In this context, it is worth mentioning an observation founded on extended and deep research of all Romance languages made by Eugeniu Coșeriu, one of the last great European Romanists, namely that "Romanian, as a historical language, is more unitary than other Romance languages: more unitary than Italian (the primary dialects of which sometimes present radical differences), more unitary than French, and as unitary as historical Spanish, with its three primary dialects (Asturian-Lyonnaise, Castilian, and NavaroAragonese)" (Coșeriu, 2005, p. 116).

Consequently, Mariana Bara should leave aside her speculations on, and mystifying interpretations of the so-called "Aromanian language", since they are closer to politics rather than to science. If not for scientific reasons, at least, out of respect for Gustav Weigand, who, in his own times, was a "complete" dialectologist (cf. Arvinte, 1993, p. 30).

\section{References}

Arvinte, V. (1993). Contribuția lui Gustav Weigand la dezvoltarea dialectologiei românești, în „Anuar de lingvistică și istorie literară”, anul XXXIII, seria A. Lingvistică, p. 29-43.

Arvinte, V. (2008). Român, românesc, România. Studiu filologic. Ediția a III-a, definitivă, Casa Editorială „Demiurg”, Iaşi.

Bardu, N. (2004). Limba scrierilor aromânești de la sfârșitul secolului al XVIII-lea (Cavalioti, Daniil, Ucuta), Ovidius University Press, Constanța.

Burileanu, C.N. (1906). Dela Romănii din Albania, București.

\footnotetext{
${ }^{9}$ In reproducing this quotation we have substituted the term armâni, for the incorrect one, aromâni, which Bandu and Bara use, as Gustav Weigand demands in his specifications to the two volumes of Die Aromunen: II (1894), p. VIII and I (1895), p. VII (see supra).
} 
Capidan, Th. (1931). Fărșeroții. Studiu lingvistic asupra românilor din Albania, în „Dacoromania”, anul VI, 1929-1930, p. 1-210.

Capidan, Th. (1932). Aromânii. Dialectul aromân. Studiu lingvistic, „Imprimeria Națională”, Bucureşti.

Coșeriu, E. (2005). Limba română - limbă romanică, Editura Academiei Române, Bucureşti.

Dictionnaire 1994 = Dictionnaire Hachette enciclopédique illustré, Paris.

Lascu, S. (2003). Periegheze ale românilor din țară la frații din Balcani (1852-1914), în vol. Istorie și diplomație în relațiile internaționale, Ovidius University Press, Constanța.

Neiescu, P. (1997). Mic atlas al dialectului aromân din Albania și din Fosta Republică Iugoslavă Macedonia, Editura Academiei Române, Bucureşti.

Nenițescu, I. (1895). Dela Românii din Turcia Europeană, București.

Papahagi, Per. (1909). Scriitori aromâni în secolul al XVIII-lea (Cavalioti, Ucuta, Daniil), București.

Saramandu, N. (1984). Aromâna, în Tratat de dialectologie românească, Scrisul românesc, p. 423-476, Craiova.

Saramandu, N. (2003). Studii aromâne și meglenoromâne, Editura Academiei Române, București.

Saramandu, N. (2004). Romanitatea orientală, Editura Academiei Române, Bucureşti.

Saramandu, N. (2007). Aromâna vorbită în Dobrogea. Texte dialectale și glosar, Editura Academiei Române, București.

Ureche, Gr. (1987). Letopisețul Țării Moldovei, Editura Minerva, Bucureşti.

Weigand, G. (1894). Die Aromunen. Ethnographish - philologisch - historische Untersuchungen über das Volk sogenannten MakedoRomanen oder Zinzaren, zweiter Band, Leipzig.

Weigand, G. (1895). Die Aromunen. Ethnographish - philologisch - historische Untersuchungen über das Volk sogenannten MakedoRomanen oder Zinzaren, erster Band, Leipzig.

Weigand, G. (2014). Armânii. Cercetări etnografice-filologice-istorice asupra poporului așa-numiților macedo-romani sau țințari. Volumul I. Ţară și oameni, București. 